\title{
Integrin Alpha-D
}

National Cancer Institute

\section{Source}

National Cancer Institute. Integrin Alpha-D. NCI Thesaurus. Code C120292.

Integ rin alpha-D (1161 aa, $\sim 127 \mathrm{kDa})$ is encoded by the human IT GAD gene. This protein plays a role in cell-cell and cell-extracellular matrix interactions. 